\title{
Democratic Governance Of The Euro: Two Practical Suggestions
}

VB verfassungsblog.de/democratic-governance-euro-europe/

Mattias Kumm Mi 23 Mai 2012

Mi 23 Mai

2012

By MATTIAS KUMM

On May 10 my colleague Miguel Maduro and I presented a policy report at a 3-hour High Level Policy Seminar at the EUI in Florence on the Democratic Governance of the Euro, in which the Commission President Barroso was an active participant. The event itself took place under Chatham House Rules, so the following will not say anything about positions taken by participants and merely elaborate on two core points that were featured in the report and that were the focal point of discussion, in the hope that these points might also be of interest to readers of the Verfassungsblog. (The report itself, co-authored by Miguel Maduro, Bruno de Witte and myself, was the result of collaboration of an international group of economists, political scientists and lawyers that formed a working group under the auspices of the Global Governance Center at the EUI.)

The European financial crisis is not just a technical crisis and it will not be resolved a few Council agreements and technical fixes. It raises profound political questions that affect the future of the European Union as a whole. At the heart of the crisis are democratic problems. The crisis is in part the result of democratic failures of the states that the EU needs to help correct. The financial troubles of a few states - in part the unintended consequences of seizing opportunities provided by the internal market - became a problem for all. Furthermore the problem of effectively regulating highly mobile players in capital markets, to ensure that their activities do not burden outsiders with inexorable costs - a democratic problem that can not be effectively solved on the level of Member States - has resulted in significantly worsening state budgetary situations, as banks effectively socialized risks and privatized profits. Any European attempts to institutionally address these highly contentious issues, which will inevitably have considerably distributive effects, will itself have to rely on the kind of political capital that only robust forms of democratic legitimation can provide. So what can be done to address these problems? There are two things that could happen on the EU level that would go some way to address these concerns. Both are possible within the parameters of the existing constitutional framework and do not require Treaty changes.

\section{Electoral choice, and why it matters}

First, it is high time to be serious about proposals endorsed among others by current President of the European Parliament Martin Schulz and Wolfgang Schäuble to make the elections for the European Parliament genuine European elections for the choice of the President of the European executive. For this to happen, it would be sufficient for the different European political groups to present competing candidates before the next election. If the election campaign would focus on this, the European Council would, in practice, have to appoint the winning candidate. Such a shift is of fundamental importance and the reasons sometime invoked against it are not persuasive.

It is of fundamental importance, because we should not be surprised to see that European citizens disagree about the kind of policy measures that are the best response to the financial crisis and other political issues that the EU rightly addresses through legislation. It is a mistake to insist, as national politicians invariably do, when they defend the measures taken at late night Council meetings under the current regime of executive dominated intergovermentalism, that there is no alternative to the decision they have made. For many citizens that is the reason why they turn their back on Europe: They do not like the policy choices generated on the European level, and there is no alternative personnel and menu of policy options present to engage with on the European level, so 
they associate Europe with those policy choices they deem undesirable. If faced with a genuine choice in personnel, programmes and policies, disgruntled citizens would be able to articulate their dissent not by turning away from Europe and seeking refuge in populist recipes. They might instead, as European citizens, vote or mobilize for an alternative Europe, personified in a different President, committed to different policies. Tying the outcome of the European elections to the determination who will be the next Commission President will lead not only to a surge of interest in European parliamentary elections and allow the Commission to more effectively fulfil the functions assigned to it, it is also likely to be the best antidote to the spread of nationalist populism and Euroscepticism.

Furthermore under the Fiscal Treaty and other fiscal crisis related legislation like the six-pack the Commission gains considerable powers to intervene in the budgetary processes of Member States, once they have shown themselves unable to meet the strict budgetary requirements imposed on them. For those powers and the discretion that comes with these powers to be exercised effectively and legitimately, the Commission must be able to rely on the kind of legitimacy that comes with direct link to the outcome of European elections. Budgetary questions were at the heart of the historical parliamentary struggles for control over a democratically unaccountable executive - they are the inner sanctum of parliamentary prerogatives - and it is unlikely that national Parliaments will give much weight to a Commission that is seen as the instrument of the collective executives of Member States.

The arguments against such elections are ultimately not persuasive. The current role of the national executives in the European decision-making process is not something that enhances the democratic legitimacy of that process. It is the result of the executive branches having captured the European decision-making process, with the accountability to national parliaments, even though not without significance, ultimately limited for structural reasons. The claim that small Member States would lose too much influence is also misguided. On the contrary, a stronger Commission President might be a more plausible counterweight to the tendency of two or three large states effectively dominating the decision-making process in Europe. The claim that European elections cannot be meaningful, because European citizens are just not interested in European elections, that there are no genuine European parties and there is no robust European public sphere etc. gets it the wrong way around. The issue is one of sequencing: Only once European elections are appropriately structured to allow citizens to choose between different leadership personnel, programs and policies are the incentives in place to develop an interest in elections, to restructure parties around European agendas and to have the media focus more strongly on European themes.

\section{Taming the Forces of the Financial Markets}

Second, the European Union can increase its democratic legitimacy by more closely aligning its policy priorities to the problems that, given the ineffectiveness of Member State solutions, it should address. The European Union is widely believed to be an institution that enables Member States collectively to reap the benefits of greater market integration, both on the European and global level, while at the same time ensuring political control over markets to ensure through appropriate regulation that mobile market actors cannot exploit the freedoms offered by transnational markets to undermine public goods.

The financial crisis has illustrated clearly that financial institutions have not been regulated sufficiently to ensure that the highly dynamic global financial markets effectively serve as the infrastructure of a stable market economy. To a large extent the so-called sovereign debt crisis is just a knock-on crisis to the 2008 financial crisis, as the example of Ireland and Spain illustrate. Meanwhile financial institutions, often bolstered by paid-for economic expertise that invokes models in which the enormity of the social costs of the financial crisis never seems to register, have emphasized not only the inefficiency but also the ineffectiveness of regulations that burden or restrict financial transactions, in part invoking global competition and exit options in globalized financial markets.

This is the type of blackmail that challenges the European Union to prove that it can actually do what it has promised: To make use of Europe's considerable regulatory capacities and market clout to tame the forces empowered by otherwise unfettered global markets. There is no reason why Europe should not follow through on 
this: The enhanced cooperation procedure can be used to overcome the lack of consensus among Member States, and an aggressive interpretation of the jurisdiction of the EU can ensure that exit options are effectively closed or minimalized.

Furthermore, the EU should provide incentives for other states to also adopt similar rules, effectively creating incentives for global harmonization. If, for example, a harmonized tax on financial transactions were to be earmarked to reduce a Member States contribution to the EU or if, for a non Member State, a similar tax on transactions involving a closer link with that state would qualify for an EU tax credit, there would be an incentive for originally disinclined states to also adopt similar taxes, and taxed financial institutions would have little incentive to lobby against it in that state, given that they would have to pay the tax in Europe anyway.

The point here is not to push for any particular mechanisms to ensure that financial institutions fulfil their function as an integral part of the infrastructure of a market economy. The point is to highlight the responsibilities and possibilities of the EU to effectively play the role of a regional regulator and global leader in the regulation of highly mobile market actors such as financial institutions that can not effectively be regulated by Member States. That is what the EU has claimed to be able to do and that is what it needs to be seen to do, if it wants to strengthen its democratic credentials.

\section{By MATTIAS KUMM}

On May 10 my colleague Miguel Maduro and I presented a policy report at a 3-hour High Level Policy Seminar at the EUI in Florence on the Democratic Governance of the Euro, in which the Commission President Barroso was an active participant. The event itself took place under Chatham House Rules, so the following will not say anything about positions taken by participants and merely elaborate on two core points that were featured in the report and that were the focal point of discussion, in the hope that these points might also be of interest to readers of the Verfassungsblog. (The report itself, co-authored by Miguel Maduro, Bruno de Witte and myself, was the result of collaboration of an international group of economists, political scientists and lawyers that formed a working group under the auspices of the Global Governance Center at the EUI.)

The European financial crisis is not just a technical crisis and it will not be resolved a few Council agreements and technical fixes. It raises profound political questions that affect the future of the European Union as a whole. At the heart of the crisis are democratic problems. The crisis is in part the result of democratic failures of the states that the EU needs to help correct. The financial troubles of a few states - in part the unintended consequences of seizing opportunities provided by the internal market - became a problem for all. Furthermore the problem of effectively regulating highly mobile players in capital markets, to ensure that their activities do not burden outsiders with inexorable costs - a democratic problem that can not be effectively solved on the level of Member States - has resulted in significantly worsening state budgetary situations, as banks effectively socialized risks and privatized profits. Any European attempts to institutionally address these highly contentious issues, which will inevitably have considerably distributive effects, will itself have to rely on the kind of political capital that only robust forms of democratic legitimation can provide. So what can be done to address these problems? There are two things that could happen on the EU level that would go some way to address these concerns. Both are possible within the parameters of the existing constitutional framework and do not require Treaty changes.

\section{Electoral choice, and why it matters}

First, it is high time to be serious about proposals endorsed among others by current President of the European Parliament Martin Schulz and Wolfgang Schäuble to make the elections for the European Parliament genuine European elections for the choice of the President of the European executive. For this to happen, it would be sufficient for the different European political groups to present competing candidates before the next election. If the election campaign would focus on this, the European Council would, in practice, have to appoint the winning candidate. Such a shift is of fundamental importance and the reasons sometime invoked against it are not 
persuasive.

It is of fundamental importance, because we should not be surprised to see that European citizens disagree about the kind of policy measures that are the best response to the financial crisis and other political issues that the EU rightly addresses through legislation. It is a mistake to insist, as national politicians invariably do, when they defend the measures taken at late night Council meetings under the current regime of executive dominated intergovermentalism, that there is no alternative to the decision they have made. For many citizens that is the reason why they turn their back on Europe: They do not like the policy choices generated on the European level, and there is no alternative personnel and menu of policy options present to engage with on the European level, so they associate Europe with those policy choices they deem undesirable. If faced with a genuine choice in personnel, programmes and policies, disgruntled citizens would be able to articulate their dissent not by turning away from Europe and seeking refuge in populist recipes. They might instead, as European citizens, vote or mobilize for an alternative Europe, personified in a different President, committed to different policies. Tying the outcome of the European elections to the determination who will be the next Commission President will lead not only to a surge of interest in European parliamentary elections and allow the Commission to more effectively fulfil the functions assigned to it, it is also likely to be the best antidote to the spread of nationalist populism and Euroscepticism.

Furthermore under the Fiscal Treaty and other fiscal crisis related legislation like the six-pack the Commission gains considerable powers to intervene in the budgetary processes of Member States, once they have shown themselves unable to meet the strict budgetary requirements imposed on them. For those powers and the discretion that comes with these powers to be exercised effectively and legitimately, the Commission must be able to rely on the kind of legitimacy that comes with direct link to the outcome of European elections. Budgetary questions were at the heart of the historical parliamentary struggles for control over a democratically unaccountable executive - they are the inner sanctum of parliamentary prerogatives - and it is unlikely that national Parliaments will give much weight to a Commission that is seen as the instrument of the collective executives of Member States.

The arguments against such elections are ultimately not persuasive. The current role of the national executives in the European decision-making process is not something that enhances the democratic legitimacy of that process. It is the result of the executive branches having captured the European decision-making process, with the accountability to national parliaments, even though not without significance, ultimately limited for structural reasons. The claim that small Member States would lose too much influence is also misguided. On the contrary, a stronger Commission President might be a more plausible counterweight to the tendency of two or three large states effectively dominating the decision-making process in Europe. The claim that European elections cannot be meaningful, because European citizens are just not interested in European elections, that there are no genuine European parties and there is no robust European public sphere etc. gets it the wrong way around. The issue is one of sequencing: Only once European elections are appropriately structured to allow citizens to choose between different leadership personnel, programs and policies are the incentives in place to develop an interest in elections, to restructure parties around European agendas and to have the media focus more strongly on European themes.

\section{Taming the Forces of the Financial Markets}

Second, the European Union can increase its democratic legitimacy by more closely aligning its policy priorities to the problems that, given the ineffectiveness of Member State solutions, it should address. The European Union is widely believed to be an institution that enables Member States collectively to reap the benefits of greater market integration, both on the European and global level, while at the same time ensuring political control over markets to ensure through appropriate regulation that mobile market actors cannot exploit the freedoms offered by transnational markets to undermine public goods.

The financial crisis has illustrated clearly that financial institutions have not been regulated sufficiently to ensure that the highly dynamic global financial markets effectively serve as the infrastructure of a stable market economy. To a 
large extent the so-called sovereign debt crisis is just a knock-on crisis to the 2008 financial crisis, as the example of Ireland and Spain illustrate. Meanwhile financial institutions, often bolstered by paid-for economic expertise that invokes models in which the enormity of the social costs of the financial crisis never seems to register, have emphasized not only the inefficiency but also the ineffectiveness of regulations that burden or restrict financial transactions, in part invoking global competition and exit options in globalized financial markets.

This is the type of blackmail that challenges the European Union to prove that it can actually do what it has promised: To make use of Europe's considerable regulatory capacities and market clout to tame the forces empowered by otherwise unfettered global markets. There is no reason why Europe should not follow through on this: The enhanced cooperation procedure can be used to overcome the lack of consensus among Member States, and an aggressive interpretation of the jurisdiction of the EU can ensure that exit options are effectively closed or minimalized.

Furthermore, the EU should provide incentives for other states to also adopt similar rules, effectively creating incentives for global harmonization. If, for example, a harmonized tax on financial transactions were to be earmarked to reduce a Member States contribution to the EU or if, for a non Member State, a similar tax on transactions involving a closer link with that state would qualify for an EU tax credit, there would be an incentive for originally disinclined states to also adopt similar taxes, and taxed financial institutions would have little incentive to lobby against it in that state, given that they would have to pay the tax in Europe anyway.

The point here is not to push for any particular mechanisms to ensure that financial institutions fulfil their function as an integral part of the infrastructure of a market economy. The point is to highlight the responsibilities and possibilities of the EU to effectively play the role of a regional regulator and global leader in the regulation of highly mobile market actors such as financial institutions that can not effectively be regulated by Member States. That is what the EU has claimed to be able to do and that is what it needs to be seen to do, if it wants to strengthen its democratic credentials.

LICENSED UNDER CC BY NC ND

SUGGESTED CITATION Kumm, Mattias: Democratic Governance Of The Euro: Two Practical Suggestions, VerfBlog, 2012/5/23, http://verfassungsblog.de/democratic-governance-euro-europe/. 